\title{
Penggunaan Lahan dalam Peningkatan Ekonomi Masyarakat Dengan Beradaptasi Pada Lingkungan
}

\author{
Hermi Zaswita $^{1}$, Ismail ${ }^{2}$, Amalia Novarita ${ }^{3}$, dan Syamsul Fajarudin ${ }^{4}$ \\ ${ }^{1}$ Program Studi Pendidikan Bahasa Inggris, STKIP Muhammadiyah Sungai Penuh \\ ${ }^{2,4}$ Program Studi Pendidikan Geografi, Universitas Islam Negeri Sultan Syarif Kasim Riau \\ 3 Program Program Studi Pendidikan Geografi, Universitas Tadulako \\ e-mail: zaswitahermi@gmail.com, ismail05@uin-suska.ac.id, amalia@untad.ac.id, \\ 12011310096@students.uin-suska.ac.id
}

\begin{abstract}
ABSTRAK. Morfologi Kota Sungai Penuh memiliki relief yang kasar oleh karena itu perlunya analisis karakteristik penggunaan lahan objek wisata Bukit Khayangan. Adapun tujuan penelitian ini adalah untuk mengetahui karakteristik penggunaan lahan objek wisata Bukit Khayangan, analisis dari lokasi, morfologi dan aksesibilitas objek wisata Bukit Khayangan kemudian hasil dari analisis menjadi rumusan alternatif-alternatif dan menyusun arah kebijakan pengembangan objek wisata Bukit Khayangan. Jenis penelitian ini adalah Mixed Methods dan penentuan informan dilakukan secara Purposive sampling. Teknik pengumpulan data dilakukan melalui observasi, wawancara, dokumentasi, dan kuesioner. Pengolahan data dilakukan dengan analisis GIS untuk menganalisa lokasi, morfologi, dan aksesibilitas. Untuk merumuskan prioritas arahan kebijakan menggunakan analisis AHP. Hasil temuan penelitian berdasarkan lokasi, morfologi, dan aksesibilitas maka dibuat arahan kebijakan pengembangan yang harus dilakukan pemerintah dengan prioritas atau urutan kebijakan pengembangan yakni: (1) meningkatkan penguatan stabilitas lereng (0,844); (2) melakukan promosi melalui paket wisata $(0,785)$; (3) melengkapi dan memperbaiki sarana dan prasana $(0,739)$; (4) meningkatkan pemeliharaan dan pelestarian lingkungan (0,737); (5) Menerapkan dan meningkatkan koordinasi dengan Stakeholder (0,732). Kesimpulan dari penelitian adalah objek wisata Bukit Khayangan memiliki lokasi yang strategis terletak pada posisi sentral namun berada pada daerah kemiringa lereng 15-25\% (Agak Curam) dan jenis tanah Padsolik yang peka erosi maka penggunaan lahan oleh masyarakat dan pemerintah dengan menfaatkan kendahan alam tanpa merusak struktur tanah.unakan.
\end{abstract}

Kata kunci: Pariwisata, Lokasi, Morfologi, Aksesibilitas, Kebijakan unakan huruf Garamond, 10pt, lower case; antara 4 - 8 katakunci..

\section{PENDAHULUAN}

Dilihat dari morfologinya, Indonesia merupakan negara yang memiliki beragam objek wisata baik alam, buatan maupun budaya. Ini disebabkan negara Indonesia terletak pada dua lempengan yang menjadikan Indonesia memiliki beragam objek wisata alam seperti pegunungan, bukit, pantai, air terjun, danau dan flora. Selain itu, Indonesia merupakan salah satu peradaban kuno, bekas penjajahan yang menjadikan Indonesia memiliki beragam suku, ras, dan peninggalan yang dapat dijadikan icon wisata. Jika potensi wisata ini di kelola dengan baik tentu akan berdampak positif yakni meningkatnya pertumbuhan ekonomi.(Damardjati, 1995)(Stanton, 1996)

Sebagai salah satu tujuan wisata, Kota Sungai Penuh memiliki potensi wisata yang cukup potensial dan beragam, mulai dari objek wisata alam seperti gua, bukit, pegunungan, dan air terjun. Selain 
itu terdapat juga potensi seni budaya dan peninggalan sejarah yang beragam dan tersebar dihampir 8 Kecamatan yang ada di Kota Sungai Penuh.

Dari sekian objek wisata yang telah di kelola salah satunya adalah objek wisata Bukit Khayangan. Objek wisata Bukit Khayangan merupakan objek wisata yang berlatar belakang kondisi alam serta pemandangan panorama. Dari atas objek wisata Bukit Khayangan kita bisa melihat pemandangan seluruh Kota Sungai Penuh dan Kabupaten Kerinci. Selain itu kita bisa melihat Danau Kerinci dan Gunung Kerinci dari kejauhan. Dengan kondisi panorama yang memukau objek wisata Bukit Khayangan sangat tepat untuk dijadikan tempat berekreasi keluarga untuk menghilangkan penat dan pengunjung juga dapat menyalurkan hobi dengan mendaki bukit.

Lokasi objek wisata Bukit Khayangan memiliki potensi yang baik untuk dikembangkan karena berada berdekatan dengan hutan Taman Nasional Kerinci Seblat (TNKS) yang dapat menjadi daya tarik bagi wisatawan. Selain itu, wilayah Kota Sungai Penuh berada di antara Kabupaten atau Provinsi tetangga seperti Kabupaten Pesisir Selatan dan Kabupaten Solok Selatan yang berada di Provinsi Sumatera Barat serta Kabuapten Muko-Muko, Provinsi Bengkulu. Melihat hal tersebut, lokasi Kota Sungai Penuh khususnya objek wisata Bukit Khayangan sangat strategis di mana arus wisatawan bisa memasuki Kota Sungai Penuh dari Provinsi dan Kabupten sekitarnya selain dari Kota Jambi.

Morfologi Kota Sungai Penuh memiliki relief yang kasar, hal ini disebabkan Kota Sungai Penuh berada pada daerah ketinggian $\pm 1800 \mathrm{Mdpl}$. Dengan relief yang kasar tersebut, maka bentuk lahan yang terbentuk secara alami di Kota Sungai Penuh, khususnya objek wisata Bukit Khayangan akan memiliki keunikkan tersendiri dan hal tersebut sangat mendukung dalam pengembangan objek wisata.(Tavallaee et al., 2014)

Berdasarkan penjelasan paragraf di atas, maka dapat disimpulkan bahwa objek wisata Bukit Khayangan sangat besar potensinya. Perkiraan kontribusi yang peneliti lakukan memberi sumbangsih yang cukup besar dalam menyumbang Pendapatan Asli Daerah. Ditambah lagi objek wisata Bukit Khayangan berada pada lokasi yang strategis dan memiliki morfologi yang unik sangat mendukung dalam pengembangannya. Dalam usaha pengembangannya, dibutuhkan peran pemerintah yakni dinas terkait dalam merumuskan strategi dan pengambilan kebijakan yang tepat. Pengembangan yang tepat menurut peneliti adalah pengembangan yang meninjau terlebih dahulu bagaimana karakteristik lokasi kemudian mengembangkannya dengan mengoptimalkan posisi lokasi, morfologi dan aksesibilitas yang ada sehingga memberi kontribusi bagi pemerintah daerah dalam meningkatkan pendapatan daerah (PAD). Oleh karena itu, perlu adanya penyajian informasi wilayah pengembangan objek wisata Bukit Khayangan yang dapat diwujudkan dalam bentuk analisis lokasi, morfologi dan aksesibilitas.(Tarigan, 2010)

\section{METODE}

Metode penelitian yang digunakan adalah Mixed Methods. Pada tahap pertama akan dilakukan pengumpulan data kuantitatif dan data kualitatif, setelah itu akan dilakukan analisis data kuantitatif dan data kualitatif sesuai dengan analisis masing-masing. Kemudian penggabungan data kualitatif dengan data kuantitatif ini biasanya didasarkan pada hasil-hasil yang telah diperoleh pada tahap pertama. Penggabungan kedua data ini terjadi ketika peneliti menghubungkan antara analisis data kualitatif dengan pengumpulan data kuantitatif. Teknik pengumpulan data dilakukan melalui observasi, wawancara, dokumentasi, dan kuesioner. Pengolahan data dilakukan dengan analisis GIS untuk menganalisa lokasi, morfologi, dan aksesibilitas. Analisis Sistem Informasi Geografi (SIG) maksudnya di sini adalah analisis peta yang digunakan dalam penelitian ini. Adapun analisis peta dalam penelitian ini adalah peta yang berkaitan dengan peta lokasi dari objek wisata Bukit Khayangang, morfologi objek wisata Bukit Khayangan dan peta yang berhubungan dengan aksesibilitas dari objek wisata Bukit Khayangan. Alat analisis peta dalam penelitian ini menggunakan software Argis 10.1 untuk mengoverlay peta sehingga menghasilkan kenampakan yang diinginkan dalam mencari data penelitian. Untuk melihat kesesuaian lahan dari objek wisata 
Bukit Khayangan mengacu pada standar teknis fungsi kawasan menurut SK Menteri Pertanian No. 837/KPT/UM/11/1980 dan SK Menteri Pertanian No. 638/KPt/UM/08/1981. Parameter yang digunakan yaitu kemiringan lereng, jenis tanah dan intensitas curah hujan. Untuk merumuskan prioritas arahan kebijakan menggunakan analisis AHP melalui tahapan identifikasi sistem yaitu untuk mengidentifikasi permasa-lahan dan menentukan solusi yang diinginkan, penyusunan struktur hirarki berupa penentuan tujuan, sub tujuan (berdasarkan permasalahan yang terjadi), penentuan kriteria dan alternatif berdasarkan hasil penelitian (Analisis SIG) dan diskusi dengan key persons, penyebarkan kuesioner kepada informan dengan membuat matriks perbandingan berpasangan, penilaian matriks menggunakan program expert choise versi 3.0, rekapitulasi hasil ranking prioritas strategi yang dipilih.(Woro, 2019)

\section{HASIL DAN PEMBAHASAN}

\section{Hasil}

\section{a. Karakteristik Objek Wisata Bukit Khayangan}

Karakteristik kawasan objek wisata Bukit Khayangan dengan luas kawasan \pm 3,5 Ha dengan kondisi kawasan yang tidak datar. Pada bagian timur kawasan merupakan bibir lereng Bukit Khayangan, disitu merupakan view pemandangan dari objek wisata Bukit Khayangan. Pada bagian utara juga merupakan daerah terjal digunakan untuk view pemandangan. Bagian barat Kawasan Bukit Khayangan berbatasan dengan kawasan lindung TNKS, sedangkan bagian selatan berbatasan juga dengan TNKS. Untuk kawasan yang bisa dikembangkan mengarah ke barat dan selatan kawasan objek wisata hal ini di karenakan daerah ini memiliki luas dan kawasan yang cukup datar untuk digunakan sedangkan bagian timur dan utara daerah tersebut berbatasan langsung dengan daerah terjal sehingga tidak mungkin bisa digunakan.(Woro, 2019)

Objek wisata ini merupakan salah satu objek wisata unggulan Kota Sungai Penuh. Berdasarkan analisis peta penggunaan lahan Kota Sungai Penuh, objek wisata Bukit Khayangan berdekatan dengan kawasan suaka alam TNKS (Taman Nasional Kerinci Seblat). Dalam RTRW Kota Sungai Penuh (Tahun 2011-2031) dijelaskan juga bahwa bagian barat Kota Sungai Penuh merupakan kawasan pengembangan pariwisata. Kawasan ini ditetapkan sebagai kawasan pariwisata dikarenakan dipengaruhi oleh letak geografis kota yang berada di tepi Taman Nasional Kerinci Seblat (TNKS) dimanfaatkan untuk tujuan pengembangan ilmu pengetahuan, pariwisata dan rekreasi. Pengelolaan objek wisata Bukit Khayangan saat ini dikelola oleh pihak kedua (swasta). Maksudnya disini Dinas Pariwisata mengontrakkan lokasi objek wisata pada pihak swasta dengan sistem kontrak yang telah ditentukan sebelumnya. Dalam usaha pengembangannya untuk menarik minat wisatawan agar datang ke objek wisata Bukit Khayangan diperlukan kebijakan pengembangan yang tepat, pengembangan yang tepat disini berdasarkan tiga aspek yaitu lokasi, morfologi dan aksesibilitas.(Tarigan, 2010)

\section{b. Analisis Lokasi Objek Wisata Bukit Khayangan}

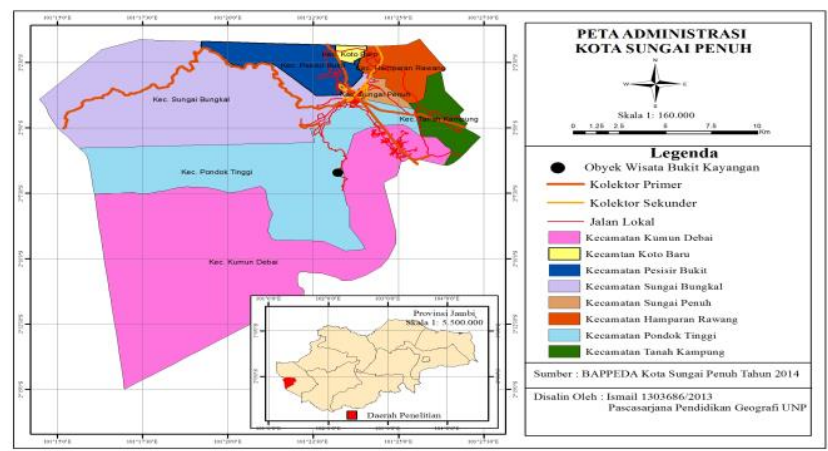

Gambar 1. Peta Lokasi Penelitian 
Lokasi objek wisata Bukit Khayangan sangat srategis, berada pada kawasan penyangga (Buffer Zone) antara kawasan Taman nasional (TNKS) dan kawasan budidaya masyarakat sehingga memiliki keindahan alam tersendiri yang yang menjadi daya tarik alami bagi objek wisata Bukit Khayangan. Berdasarkan analisis lokasi yang berpedoman pada Peraturan Menteri Pekerjaan Umum No.41/Prt/M/2007 Kawasan peruntukan pariwisata dilihat Karakteristik lokasi, objek wisata Bukit Khayangan dapat dikatakan memenuhi kriteria dalam peruntukan lokasi objek wisata alam. Berada pada daerah beriklim tropis dengan suhu rata- rata $22,3^{\circ} \mathrm{C}$, Topografi dengan ketinggian 700 sampai ketinggian lebih dari 2000 meter dpl, terpisah dari jalur regional, dan memiliki daya tarik flora dan fauna tersendiri karena berada berdekatan dengan TNKS. [7] [8]

Kota Sungai Penuh dilihat dari pusat kegiatan terletak pada posisi sentral antara Provinsi Sumatera Barat, Provinsi Jambi dan Provinsi Bengkulu, dengan PKN (Pusat Kegiatan Nasional) yang terdekat dengan Kota Sungai Penuh adalah Kota Padang (PKN Sumbar) yang jalur lintasnya melalui PKW (Pusat Kegiatan Wilayah) Muara Labuh atau PKW (Pusat Kegiatan Wilayah) Painan. Sedangkan jalur lintas menuju PKN (Pusat Kegiatan Nasional) Kota Jambi melalui PKWp Bangko dan Muaro Bungo yang merupakan PKW (Pusat Kegiatan Wilayah) terdekat dengan Kota Sungai Penuh dalam wilayah Provinsi Jambi. Muara Bungo juga merupakan kawasan andalan yang terdekat dengan Kota Sungai Penuh. Di sisi lain PKW (Pusat Kegiatan Wilayah) Muko-muko merupakan jalur lintas menuju PKN (Pusat Kegiatan Nasional) Bengkulu. Posisi yang sangat menguntungkan itu dapat mendatangkan arus wisatawan dari tiga jalur masuk yaitu dari Propinsi Sumatera Barat, Propinsi Bengkulu dan dari Propinsi jambi.[10][11]

\section{c. Analisis Morfologi Objek Wisata Bukit Khayangan}

Objek wisata Bukit Khayangan berada pada daerah tinggi dengan morfologi unik. Dalam pengembangan objek wisata harus melihat aspek dari kemampuan lahan dan kesesuaian lahan untuk minimalisir kerusakan lingkungan dan kestabilan dari lereng. Analisis kemampuan lahan objek wisata Bukit Kayang dengan parameter kemiringan lereng, tingkat erosi permukaan, drainase permukaan, tekstur tanah dan kedalaman air tanah maka diperoleh hasil kemampuan lahan dari lokasi objek wisata Bukit Khayangan sebagai berikut:

Tabel 1. Analisis Kemanpuan Lahan

\begin{tabular}{cccc}
\hline Kelas & Nilai & Kriteria & Deskripsi \\
\hline $\mathbf{1}$ & $21,1-25$ & Sangat baik & Baik \\
$\mathbf{2}$ & $17,1-21$ & $\begin{array}{c}\text { Daya dukung tinggi } \\
\text { Daya dukung baik } \\
\text { dengan sedikit faktor } \\
\text { pembatas }\end{array}$ \\
$\mathbf{3}$ & $13,1-17$ & Sedang & $\begin{array}{c}\text { Daya dukung agak baik } \\
\text { dengan beberapa faktor } \\
\text { pembatas }\end{array}$ \\
$\mathbf{5}$ & $9,1-13$ & Jelek & $\begin{array}{c}\text { Kondisi jelek dengan } \\
\text { banyak faktor pembatas } \\
\text { Kondisi sangat jelek }\end{array}$ \\
\hline Sumber: Hasil analisis dan pengolahan peneliti &
\end{tabular}

Analisis kemampuan lahan objek wisata Bukit Kayang dengan parameter kemiringan lereng, tingkat erosi permukaan, drainase permukaan, tekstur tanah dan kedalaman air tanah maka diperoleh hasil kemampuan lahan dari lokasi objek wisata Bukit Khayangan adalah kriteria baik. Artinya, kemampuan lahan untuk peruntukan tertentu baik dengan daya dukung fisik yang memiliki sedikit faktor pembatas atau penghambat. Faktor pembatas atau penghambat disini adalah kemiringan lereng mengingat kondisi kemiringan lereng lokasi objek wisata Bukit Khayangan berada pada kemiringan 15-25\% dengan klasifikasi agak curam dalam pemamfaatanya memerlukan rekayasa keteknisan yang benar. (Hermon \& Khairani, 2009)

Selain kemampuan lahan, kesesuaian lahan berdasarkan fungsi kawasan juga harus diperhatikan dalam pengembangan objek wisata Bukit Khayangan. 
Tabel 2 Analisis Kesesuaian Lahan

\begin{tabular}{lcrrc}
\hline Parameter & Interval & Skor & Jumlah & Fungsi \\
\hline Lereng & $15-25 \%$ & 60 & & Kawasan \\
Jenis tanah & Padsolik & 60 & 130 & Penyangga \\
Intensitas hujan & $0-13,6$ & 10 & & (Buffer zone) \\
\hline
\end{tabular}

Sumber: Hasil analisis dan pengolahan peneliti

Hasil yang diperoleh Kesesuaian lahan Objek wisata Bukit Khayangan memiliki jumlah nilai sebesar 130. Hal tersebut berarti bahwa lahan yang terdapat di Lokasi Objek wisata Bukit Khayangan memiliki kesesuaian fungsi lahan sebagai Kawasan Penyangga (Buffer zone). Menurut Bismark dan Reny (2006) daerah penyangga berperan sangat penting bagi kelestarian suaka alam dan kawasan pelestarian alam sebagai buffer dalam mengurangi tekanan penduduk terhadap kawasan pada daerah atau desa sekitar kawasan yang berinteraksi tinggi dengan memadukan kepentingan konservasi dan perekonomian masyarakat sekitarnya. (Tarigan, 2010)

Kawasan penyangga di Objek wisata Bukit Khayangan memiliki kelerengan tidak lebih dari 25\% dengan klasifikasi lahan agak curam dan jenis tanah Padsolik yang dengan klasifikasi kepekaan terhadap erosi untuk tanah Padsolik yaitu peka terhadap erosi. Jenis tanah di objek wisata Bukit Khayangan tersebut cocok untuk budidaya seperti hutan produksi terbatas, perkebunan (tanaman keras), kebun campur dan lainnya yang sejenis namun harus sesuai dengan aturan-aturan yang berlaku karena jika terjadi kesalahan dalam pengolahannya dapat menimbulkan bahaya longsor dan merusak lingkungan. Melihat kondisi alam yang begitu akibatnya daerah tersebut perlu perlakuan khusus untuk dikembangkan dan direkomendasikan sebagai daerah daerah pembatas antara kawasan lindung dengan aktivitas ekonomi masyarakat. Daerah penyangga (buffer) tersebut dapat dikembangkan berupa objek wisata alam yang sedikit pembangunan fisik lebih mengutamakan keaslian dari alamnya sendiri. (Hermon \& Khairani, 2009)(M. Bismark \& Sawitri, 2014)

\section{d. Analisis Aksesibilitas Objek Wisata Bukit Khayangan}

Berdasarkan analisis aksesibilitas dengan parameter yang digunakan berupa jarak, kondisi jalan, kendaraan menuju objek wisata, terminal dan akomodasi maka diperoleh hasil sebagai berikut:

Tabel 3. Analisis Aksesibilitas

\begin{tabular}{cccccc}
\hline Aspek & Faktor & Kriteria & Skor & Bobot & $\begin{array}{c}\text { Skor x } \\
\text { Bobot }\end{array}$ \\
\hline Jarak & $\begin{array}{c}\text { Jarak pusat kota } \\
\text { dengan objek } \\
\text { wisata 5 - 15 Km } \\
\text { Jalan aspal }\end{array}$ & 6 & 3 & 18 \\
Aksesibilitas & $\begin{array}{c}\text { Kondisi jalan } \\
\text { Kendaraan } \\
\text { menuju objek } \\
\text { wisata } \\
\text { Terminal }\end{array}$ & $\begin{array}{c}\text { Umum roda } 2 \\
\text { sampai roda 4 }\end{array}$ & 9 & 3 & 27 \\
Akomodasi & $\begin{array}{c}\text { Terminal bus, } \\
\text { bandara, dan ojek } \\
\text { Berada jauh dari } \\
\text { areal objek wisata } \\
\text { Jumlah }\end{array}$ & 9 & 3 & 3 & 27 \\
\hline
\end{tabular}

Sumber: Hasil analisis dan pengolahan peneliti

Hasil analisis aksesibilitas adalah tinggi (skor 108). Selain itu, sarana dan prasarana yang ada dalam objek wisata Bukit Khayangan berupa gazebo 1 buah, pondok atau saung 2 buah, tempat peristirahatan, WC umum, dan parkir roda dua dan empat. Semua fasilitas tersebut dalam keadaan tidak terawat. Dari wawancara peneliti di Dinas Pariwisata dan Kebudayaan Kota Sungai Penuh hal ini disebabkan minimya dana yang dibutuhkan dalam perawatan fasilitas yang ada. Kondisi 
jalan menuju objek wisata berupa jalan aspal dalam kondisi baik dan bisa dilewati kenderaan roda dua dan empat. Sayangnya belum ada penginapan di dalam lokasi objek wisata, penginapan hanya terdapat di pusat Kota Sungai Penuh saja. (Tarigan, 2010)

\section{e. Arahan Kebijakan Pengembangan Objek Wisata Bukit Khayangan}

Berdasarkan temuan penelitian maka dapat dikelompokan alternatif-alternatif pengembangan objek wisata ke dalam kriteria kebijakan pengembangan yang diperoleh melalui FGD. Pemberian bobot didasarkan pada kriteria penilaian AHP yang dirumuskan Saaty dalam Sismantoro (2012). Nilai-nilai perbandingan relatif diolah dengan menggunakan program Expert Choise versi 3.0 untuk menentukan peringkat dari seluruh alternatif yang ada. Prioritas kebijakan berdasarkan perhitungan Consistency ratio dengan syarat data harus bersifat konsisten atau $<0,1$, artinya bobot nilai dari setiap indikator dikatakan konsisten sehingga dapat digunakan untuk analisis lebih lanjut (Almegi, 2019). Pada gambar 2 menunjukkan nilai Consistency ratio didapat adalah 0,033. Artinya hierarki kebijakan yang disusun dalam penelitian ini adalah konsisten dan dapat digunakan. (Nasibu, 2009)

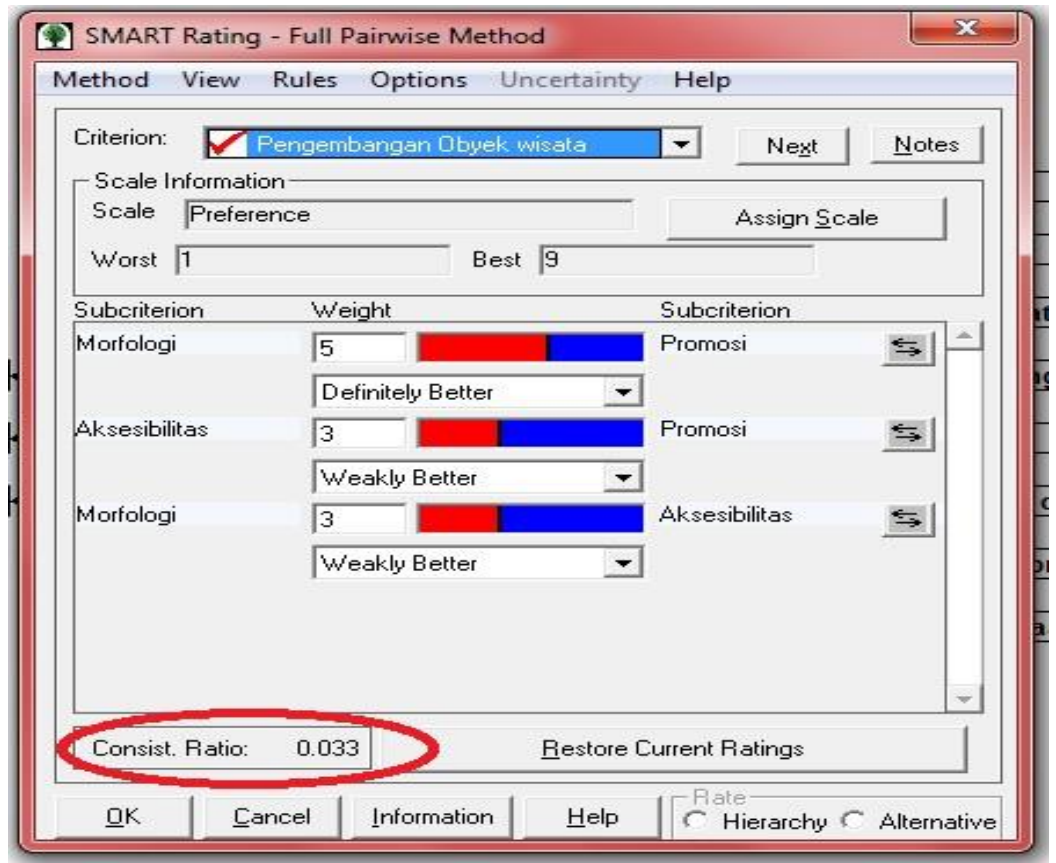

Gambar 2. Consistency ratio

Setelah dilakukan perhitungan Consistency ratio didapatkanlah alternatif kebijakan Alternatif kebijakan yang menjadi prioritas pengembangan seperti gambar 12 di bawah ini.

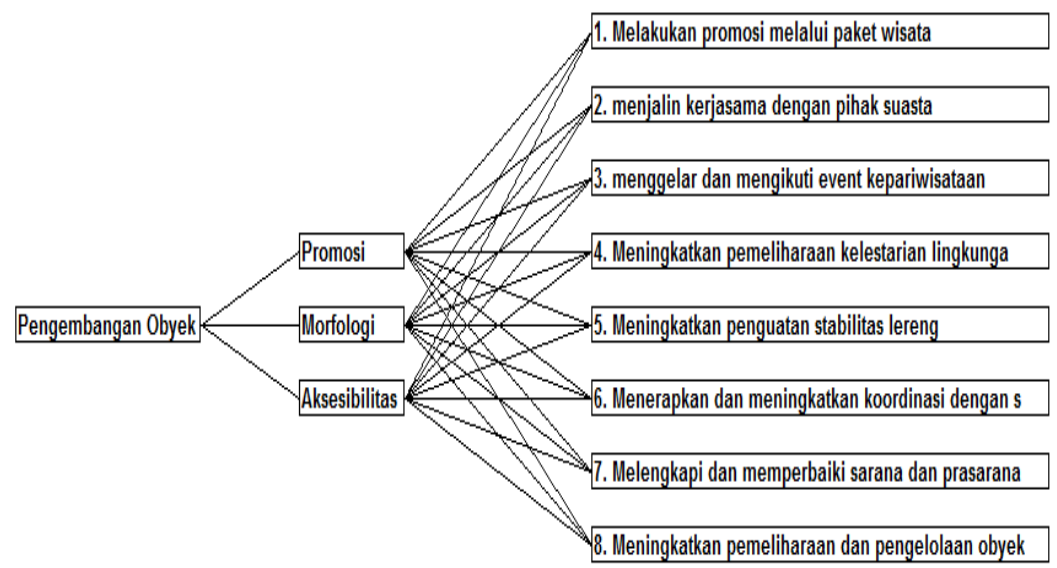

Gambar 3. Hirarki Kebijakan 
Berdasarkan hasil olahan data Expert Choise versi 3.0 maka dapat dikelompokan alternatif-alternatif pengembangan objek wisata kedalam kriteria kebijakan pengembangan yang diperoleh sebagai berikut:

a) Menjalin kerjasama dengan pihak swasta $(0,726)$

b) Melakukan promosi melalui paket wisata $(0,785)$

c) Menggelar dan mengikuti event kepariwisataan $(0,671)$

d) Meningkatkan penguatan stabilitas lereng $(0,748)$

e) Meningkatkan pemeliharaan kelestarian lingkungan Objek Wisata $(0,737)$

f) Menerapkan dan meningkatkan koordinasi dengan stakeholder $(0,732)$.

g) Melengkapi dan memperbaiki sarana prasarana pendukung kegiatan kepariwisataan (0,739).

h) Meningkatkan Pemeliharaan dan pengelolaan terhadap objek wisata $(0,704)$.

Dari Alternatif Kebijakan yang didapat, maka dipilih 5 prioritas yang paling besar skornya yaitu : (1) melakukan promosi melalui paket wisata $(0,785)$; (2) meningkatkan penguatan stabilitas lereng $(0,748)$; (3) melengkapi dan memperbaiki sarana dan prasana $(0,739)$; (4) meningkatkan pemeliharaan dan pelesatraian lingkungan $(0,737)$; (5) Menerapkan dan meningkatkan koordinasi dengan Stakeholder (0,732). (Nasibu, 2009)(Alfiah. et al., 2021)

\section{KESIMPULAN}

Berdasarkan hasil penelitian dan pembahasan, maka dapat disimpulkan bahwa karakteristik kawasan objek wisata Bukit Khayangan didominasi daerah yang tidak datar dan hanya bagian barat dan selatan yang bisa dikembangkan, Objek wisata Bukit Khayangan di tinjau dari lokasi sangat strategis, di tinjau dari morfologi objek wisata Bukit Khayangan memiliki kemampuan lahan berada pada kriteria baik dan kesesuaian lahan berada pada kawasan penyangga, di tinjau dari aksesibilitas objek wisata Bukit Khayangan mudah di jangkau, dan Analisis kebijakan menggunakan program Expert Choise versi 3.0 maka dapat diambil prioritas kebijakan yang didapat yaitu melakukan promosi melalui paket wisata $(0,785)$, meningkatkan penguatan stabilitas lereng $(0,748)$, melengkapi dan memperbaiki sarana dan prasana $(0,739)$, meningkatkan pemeliharaan dan pelesatraian lingkungan $(0,737)$ dan Meningkatkan koordinasi dengan Stakeholder $(0,732)$.

\section{REFERENSI}

Alfiah., Darni., Moenanda., M. S., \& Ismail. (2021). Analisis Bentuk Kewirausabaan Mahasiswa pada Revolusi Industri 4.0 di Perguruan Tinggi Kota Pekanbaru. 4. https://doi.org/10.24014/ekl.v4i2.15620

Almegi. (2019). Kerentanan Wilayah Terhadap Penuruhan Harga Crude Palm Oil (CPO) Dunia di Kabupaten Tanjung Jabung Barat Bagian Hulu. Jurnal Spasial, 6(3), 104-111.

http://ejournal.stkip-pgri-sumbar.ac.id/index.php/spasial/article/view/4041

Damardjati, R. . (1995). Istilah-Istilah Dunia Pariwisata. Pradnya Paramita.

Hermon, D., \& Khairani. (2009). Geografi Tanah. Yayasan Jihadul Khair Center.

M. Bismark, \& Sawitri, R. (2014). Nilai Penting Taman Nasional. In A. Susmianto., P. Setio., \& Harisetijono (Eds.), Nuevos sistemas de comunicación e información.

Nasibu, I. Z. (2009). Penerapan Metode AHP Dalam Sistem Pendukung Keputusan Penempatan Karyawan Menggunakan Aplikasi Expert Choice. Jurnal Pelangi Ilmu, 2(5), 180.

https://doi.org/10.34818/INDOJC.2021.6.1.525

Stanton, W. J. (1996). Prinsip Pemasaran (terjemahan). In Edisi 7, Jilid 1 (Ed. 7, cet). Erlangga. Tarigan, R. (2010). Perencanaan Pembangunan Wilayab: Cetakan kelima. Bumi Aksara. 
Tavallaee, S., Asadi, A., Abya, H., \& Ebrahimi, M. (2014). Tourism planning: an integrated and sustainable development approach. In Management Science Letters. JOHN WILLEY \& SONS. https://doi.org/10.5267/j.msl.2014.11.008

Woro, S. (2019). Perencanaan Tata Ruang Wilayah Kota. In PenataanRuang.com. Fakultas Geografi UGM. 